\title{
Vitamin D Deficiency as a Risk Factor for Schizophrenia: A meta-analysis of Observational Studies
}

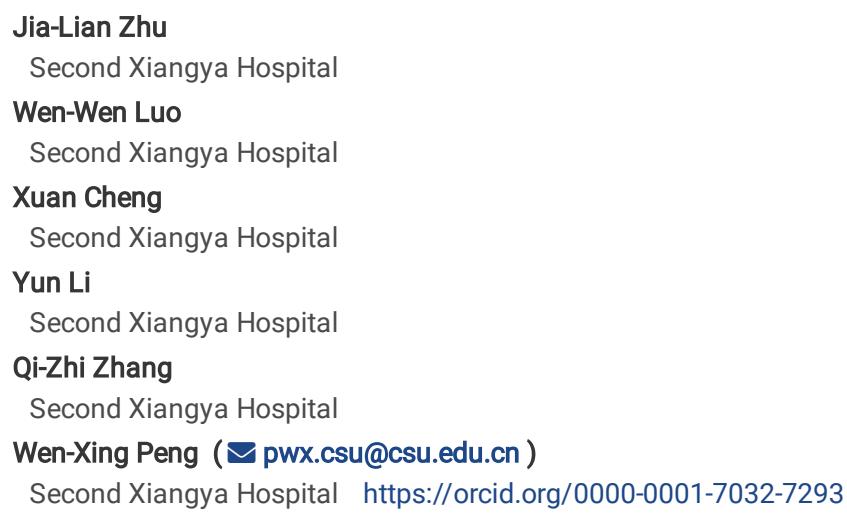




\section{Abstract}

Background: Schizophrenia is a heterogeneous disorder in which there is interaction between genetic and environmental factors. Study have found that vitamin D deficiency is a risk factor for schizophrenia. We conducted a meta-analysis to investigate the relationship between schizophrenia and blood vitamin D level.

Methods: A systematic review and meta-analysis have been conducted. All published observational articles have been searched from PubMed, Web of Science, Scopus, Cochrane library and Embase until September 2019. The Newcastle-Ottawa scale was used to examine the quality of the included studies.

Results: A total of 38 articles have been included in this study. The lower level of vitamin D was found in people with schizophrenia compared with controls (WMD $=-4.50,95 \% \mathrm{Cl}[-6.69,-2.32])$. Subgroup analyses based on study design, the patient's hospitalization status, quality of the study, outcomes, and the country explained part of between-study heterogeneity. No significant differences in publication bias were observed. The overall prevalence of vitamin D deficiency and insufficiency in schizophrenic patients were $66 \%, 95 \% \mathrm{Cl}[57 \%-76 \%]$ and $76 \%, 95 \% \mathrm{Cl}[69 \%, 83 \%]$, respectively. Subjects with schizophrenia were more likely to have vitamin D deficiency or vitamin D insufficiency compared to controls $(2.03,95 \% \mathrm{Cl}[1.49,2.77] ; 2.43,95 \% \mathrm{Cl}[1.40,4.23])$.

Conclusion: The results of this systematic review show that low vitamin D levels might contribute to the development of schizophrenia. The prevalence of vitamin D deficient or insufficient in schizophrenia was higher than that in healthy controls or another psychotic disease .

\section{Background}

Vitamin D (Vit D) is an important hormone that is widely known for its essential role in calcium absorption and bone health [1]. Data support a role for Vit D within the central nervous system as a neuroprotective and dopamine modulating steroid [2]. However, Vit D deficiency is becoming a common problem in many countries. It is estimated that 1 billion people have Vit D deficiency or insufficiency worldwide [3]. Many studies have highlighted hypovitaminosis D as a potential environmental risk factor for various conditions such as multiple sclerosis, asthma, cardiovascular diseases, and, more recently, psychiatric disorders $[4,5]$. A growing body of literature is related to vitamin D status and risk of brain disorders including schizophrenia or psychosis [6]. Patients with schizophrenia, in particular, are more likely to be deficient than individuals with other psychiatric disorders [7, 8]. Incidence of Vit D deficiency was found both increased in animal models (e.g., the litter of vitamin-D depleted pregnant female rats) and in humans with developing schizophrenia [9].

Schizophrenia is a chronic and complicated disorder characterized by multifaceted psychopathology of psychotic symptoms, negative symptoms and cognitive deficits [10]. Typical symptoms can be separated into positive symptoms (e.g., hallucinations, delusions, and thought disorder), negative symptoms (e.g., deficits in social interaction, emotional expression, and motivation), and cognitive dysfunction (e.g., impaired attention/information processing, problemsolving, processing speed, verbal and visual learning, and memory and working memory) [11]. Schizophrenia lifetime prevalence is about $1 \%$ of the general population, meaning millions of people worldwide suffer from the disease [12] which contributes to a substantial burden of disease globally (13.4 million years) [13].

Epidemiological data and data on different geographical regions suggest that schizophrenia is more common in those born in winter and spring [14, 15] and its prevalence also rises with increasing latitude $[14,16]$. The prevalence is also higher in black than white [17]. For hypovitaminosis $D$ is more prominent in winter, in high latitudes, and individuals with dark skin, there is an infer that vitamin D plays a vital role in schizophrenia. Besides, deficits in nutrients and vitamin $D$ in long-term schizophrenia were observed from illness onset and were associated with worse symptomology [18]. Adults with schizophrenia also have been found to have lower serum 25-hydroxyvitamin D (25(OH)D) levels than the general population [8, 19].

A study conducted Vit D status on neonatal and risk of schizophrenia demonstrated that low vitamin D concentrations had a significantly increased risk of schizophrenia (up to twofold) compared to neonates with concentrations ranging between 40.5 and 50.9 nmol/L. Interestingly, neonates with excessive concentrations of vitamin D also had an elevated risk for this disorder [20]. While most of the epidemiological data or systematic review only reported that hypovitaminosis $D$ is associated with schizophrenia $[9,21,22]$. Another study in the neonatal population found that Vit $D$ supplementation during the first year of life was associated with a reduced risk of schizophrenia in males but not in females [23]. Some even have failed to find a significant association between Vit $D$ and schizophrenia [24]. Conclusion on the prevalence of schizophrenia between male and female was also inconsistent [25-27]. Although there was a mass of researches on the relationship of schizophrenia and Vit D deficiency, it is still worth exploring further. Therefore, we undertook a systematic review and meta-analysis to investigate whether Vit D deficiency is associated with schizophrenia.

\section{Methods}

\section{Search strategy}

A systematic research on all published articles was retrieved by searching PubMed, the Cochrane Library, Embase, ISI (Web of science) and Scopus databases using the following combination of descriptors: (schizophrenia OR psychotic disorders OR mental disorders OR psychiatric) AND (vitamin D OR 25hydroxyvitamin D OR calcidiol OR cholecalciferol OR hydroxycholecalciferols OR ergocalciferols OR 25-hydroxyvitamin D2 OR dihydrotachysterol OR calcifediol OR dihydroxycholecalciferols OR calcitriol) from inception to April, 2019. The references list of retrieved articles was also manually reviewed to identify relevant studies missed by the search strategy.

\section{Inclusion and Exclusion criteria}

The eligible studies must meet the following inclusion criteria: (1) original studies to evaluate the association of Vit D status and risk of schizophrenia; (2) providing the blood Vit D level of schizophrenic patients and control or prevalence of Vit D deficiency or insufficiency (VDD or VDI) of subjects. The animal 
experiment, review and studies focus on the effects of Vit D supplements on schizophrenia were excluded. No restrictions on study design, biomarkers of Vit D, race, disease stage or severity. We also did not include one study with the outcome of $1,25(\mathrm{OH}) \mathrm{D}_{3}$ [28]. Two studies with the cutoff point of 10 [29] or 12 $\mathrm{ng} / \mathrm{mL}$ [30] and seven studies had no cutoff point of VDD or lack of relevant data [8, 20,31-35] was excluded from this meta-analysis. We also found two other abstracts that seemed to have overlapped sample sizes [36, 37]; therefore, we included only the one with a larger sample size [36]. One study compared the difference between highland and lowland of Vit D of patients who lived in Tanah Karo also excluded[38].

\section{Data extraction and Outcomes}

All published articles were observed studies with full text or abstract, data of schizophrenia or schizoaffective or other schizophrenia spectrum disorders were merged. We collect information from each identified study include the study ID (first author and year of publication), number of each group, average age, country, diagnosis tool of schizophrenia, measurement of Vit $D$ and outcomes. The primary outcome for the study was the peripheral blood level of Vit $D$. For consistency, Vit D present in $\mathrm{nmol} / \mathrm{L}$ were converted to $\mathrm{ng} / \mathrm{mL}$ by using the conversion factor $(1 \mathrm{ng} / \mathrm{mL}=2.5 \mathrm{nmol} / \mathrm{L})$. Some studies reported medians and the interquartile range of Vit D levels[39-41], we calculated the mean and SD using required formulas [42]. One study [43] reported mean and 95\% Cl instead of SD, or means and SD of two groups such as male and female [44], respectively, we converted them to mean and SD according to the Cochrane Handbook for Systematic Reviews of Interventions. The secondary outcomes were the number of samples positive or ORs for VDD or VDI and differences between sex of serum Vit D in schizophrenic patients. VDD was defined as a serum $25(\mathrm{OH}) \mathrm{D}$, a stable marker of Vit $\mathrm{D}$ status, the concentration of $\leq 20 \mathrm{ng} / \mathrm{mL}$, which has been widely used in relative studies as the cut-off point for VDD [45]. VDI was defined as a concentration of $25(\mathrm{OH}) \mathrm{D} \leq 30 \mathrm{ng} / \mathrm{mL}$ based on most of the included studies.

\section{Quality assessment of studies}

In the current analysis, the Newcastle-Ottawa scale [46] was used to examine the quality of case-control studies and a maximum of nine scores can be awarded to each study included in this meta-analysis. The quality score of greater than 6 as high-quality studies and those with a score of 6 or fewer points were considered as low-quality studies.

For cross-section studies included in this meta-analysis, we used an 11-item checklist which was recommended by the Agency for Healthcare Research and Quality (AHRQ) [47]. An item would be scored "0" if it was answered "No" or "Unclear"; if it was answered "Yes", then the item scored '1'. Article quality was assessed as follows: low-quality = 0-3; moderate-quality = 4-7; high-quality = 8-11.

\section{Statistical analysis}

Stata, version 14.0 (Stata Corp) were applied to collect relevant data and analysis in this meta-analysis. For outcomes, we chose weighted mean difference (WMD) to assess continuous variables (i.e. periphery blood levels of vitamin D), while risk difference (RD) or odds ratio to evaluate dichotomous outcomes such as VDD or VDI. Each numerical outcome value was presented with a $95 \%$ confidence interval ( $95 \% \mathrm{Cl}$ ) as well. The standard error (SE) of the incidence of VDD or VDI were calculated for meta-analysis of the prevalence of VDD and VDI. Of note, when the incidence of VDD obey normal distribution, and $n \star P, n \star(1-P)$ were both bigger than 5, RD was used for evaluating, otherwise we used odds ratio (OR) to assess the prevalence of VDD or VDI. Differences in the prevalence of VDD and VDI between schizophrenia and controls were assessed by odds ratio. Summary estimates with their corresponding SDs were derived by the method of Der Simonian and Laird by using a random-effects model, which incorporates between-study variability. Heterogeneity across studies was assessed using the Q-statistic. Meta-regression and subgroup analyses were performed to find the source of heterogeneity using a random-effects model. Publication bias was detected by Egger's test and Begg's test, $P<0.05$ was considered a significant publication bias. In addition, the sensitivity analysis was conducted to test the stability of results by Stata 12.0 software.

\section{Results}

\section{Study characteristics}

The detailed steps of the literature search flow and screening process were depicted in Figure 1. A total of 16869 articles were identified via a primary search of the aforementioned literature databases, from which 2359 citations were removed because of duplication. Screening of article title and abstract by separate two researchers (JL Zhu and WW Luo), 14395 citations were removed due not to meet the inclusion criteria and 112 potential related articles were reminded approximately. Further assessment of full text and abstract, 36 articles did not match on the schizophrenic patients, 9 articles conducted on capable of Vit D supplementation to schizophrenia, 10 articles without full text or abstract, and 14 articles lack outcomes or relevant data. Ultimately, a total of 31 articles included 20 case-control (18 full-text articles and 2 abstracts) and 11 cross-section studies (10 full-text articles and one abstracts) were considered in this meta-analysis.

Studies characteristics were summarized in Table 1 and Table 2. Sample sizes of included studies ranged from 17 to 6241 persons, and in total 2848 participants. Age span is from 17 to 79. These papers were published between 1987 and 2018; most of the diagnosis tools of schizophrenia were DSM-IV and ICD-10. No matter measured $25(\mathrm{OH}) \mathrm{D}_{2}$ or $25(\mathrm{OH}) \mathrm{D}_{3}$ and their measurements. Sixteen of them were reported from European countries and 19 from non-

European countries. Quality assessment of studies showed that 5 of case-control studies [48-52] were considered as low-quality and the rest [24, 39, 44, 53-64] were high-quality studies. The quality score of cross-section studies showed that 3 of 11 were high-quality $[40,65,66]$, one study assessed as low-quality [36] and the rest of the studies $[41,43,67-71]$ were moderate-quality.

\section{Mean concentration of 25(OH)D and schizophrenia}


Twenty-nine study populations from 33 studies [24, 39-41, 43, 44, 48, 50, 52-65, 67, 70-75] were included in the meta-analysis of the mean level of 25(OH)D. As shown in Figure 2, the results indicated that there were statistically significant differences in mean concentration of 25(OH)D between schizophrenia and control group in case-control studies (WMD $=-5.91,95 \% \mathrm{Cl}[-7.90,-2.48], P<0.001)$ and cross-section studies $(\mathrm{WMD}=-2.60,95 \% \mathrm{Cl}[-4.20,-0.99], P=0.022)$. However, between study-heterogeneity was significant ( $Q$ test, $P<0.0001, I^{2}=96.1 \%$ ). Between group-heterogeneity implied significant difference between study design subgroups $\left(P=0.11, I^{2}=61.7 \%\right)$. Of note, the control group in the case-control studies consisted of healthy subjects with no history of psychiatric disorders while in the cross-sectional studies, psychiatric patients but non-schizophrenic were considered to be the control group. Consequently, we were able to conclude that, compared with healthy subjects or other psychiatric patients, peripheral blood mean level of $25(\mathrm{OH}) \mathrm{D}$ achieved inferior in schizophrenia patients.

To explore the source of heterogeneity, subgroup analysis (based on the quality evaluation, location, age, and hospitalized status among included observational studies) were conducted. As shown in Table 3, the results indicated that between study-heterogeneity in the age group, over 50 years old was insignificant $\left(\mathrm{I}^{2}=0 \%\right)$ while the others were significant $\left(\mathrm{I}^{2}>50 \%\right)$. Tests for subgroup difference manifested country, quality of study and hospitalization status showed no significant differences $\left(P>0.05, I^{2}<50 \%\right)$. Study design, age and outcome may be part of source of heterogeneity $\left(I^{2}>50 \%\right)$.

Besides, three studies had reported higher serum Vit D concentration for female subjects than male subjects[44, 59, 69], only Yazici, AB's study reported female had a lower levels compared with male[73]. At the same time, one research reported Caucasian subjects had significant higher 25(OH)D levels compared with African American subjects $(P<0.001)[59]$.

\section{Prevalence of VDD or VDI in schizophrenic patients}

The definition of Vit D deficiency in schizophrenia patients was different among studies. For these differences, we did a subgroup analysis. Seventeen studies with the VDD defined as lower than $20 \mathrm{ng} / \mathrm{mL}[24,35,36,39,51,61-67,70,72,73,76,77]$ and nine studies with the VDI defined as lower than $30 \mathrm{ng} / \mathrm{mL}[24,36$, $39,41,49,51,59,65,73$ ] were included in this meta-analysis. One study had considered the cutoff point of $32 \mathrm{ng} / \mathrm{mL}$ for VDD, and we summarized it into a group of VDI [41]. Of note, one citation has the result of all schizophrenic patients have the VDI (lower than $30 \mathrm{ng} / \mathrm{mL}$ ), which could not include in the comparison [29]. Results implied that the overall prevalence of VDD and VDI in schizophrenic patients were $66 \%(95 \% \mathrm{Cl}[57 \%-76 \%]$ and $76 \%(95 \% \mathrm{Cl}[69 \%$, $83 \%]$ ) (Figure 3), respectively. Heterogeneity between study was significant ( $Q$ test, $P<0.001 ; I^{2}=98 \%$ and $88 \%$ ) and heterogeneity between subgroup wasn't significant ( $\mathrm{Q}$ test, $\left.\mathrm{P}=0.27 ; \mathrm{I}^{2}=18.9 \%\right)$.

\section{ORs}

To further investigation the differences of prevalence of VDD or VDI between schizophrenia and controls, we calculated the OR of fifteen studies on VDD [24, $39,49,51,61-68,70,72,73]$ and ten studies on VDI $[24,41,49,56,58,62,63,65,70,73]$, respectively. The meta-analysis demonstrated that the odds ratio of VDD and VDI were $2.03,95 \% \mathrm{Cl}[1.49,2.77]$ and $2.43,95 \% \mathrm{Cl}[1.40,4.23]$, respectively (Figure 4 and 5$)$. Heterogeneity was significant $\left(\mathrm{I}^{2}=59 \%, P=0.002\right.$ or $\left.\mathrm{I}^{2}=64 \%, P=0.003\right)$. Subgroup analysis indicated that study design might explain part of the source of heterogeneity $\left(I^{2}=59.7 \%\right.$ and $\left.55.7 \%\right)$.

\section{Publication Bias}

A funnel plot on publication bias for mean concentration of $25(\mathrm{OH}) \mathrm{D}$ was displayed in Figure 6 , and the result of Egger's test $(\mathrm{t}=0.65, P=0.521>0.10)$, and Begg's test $(z=1.32, P=0.181>0.05)$, indicated no evidence of significant publication bias, especially cross-section studies.

\section{Sensitivity Analysis}

For the mean concentration of 25(OH)D, a sensitivity analysis was carried out to verify the stability of the result, which was done by excluding studies seriatim at a time to resynthesize the data. As Figure 7 signified, sensitivity analyses revealed that no individual studies significantly affected the mean concentration of Vit $D$, which indicated statistically robust results.

\section{Discussion}

In the present meta-analysis, we identified 24 case-control studies and 14 cross-section studies investigating the association between schizophrenia and Vit D deficiency, but no randomized control trail. Even though there were 27 studies considered high-quality, substantial heterogeneity still be observed between study estimates for schizophrenia. No matter type of schizophrenia and stage of schizophrenia, mean concentration of Vit D in individuals unveiled that significant reductions in Vit $\mathrm{D}$ among people with schizophrenia than healthy controls or other psychiatric patients $(\mathrm{WMD}=-4.50,95 \% \mathrm{Cl}[-6.69,-2.32]$, $\mathrm{P}<0.0001)$. Prevalence of deficiency $(<20 \mathrm{ng} / \mathrm{ml})$ and insufficiency $(<30 \mathrm{ng} / \mathrm{ml})$ both indicated that hypovitaminosis D was quite common in schizophrenia $(69 \%, 95 \% \mathrm{Cl}[62 \%, 76 \%])$. Odds ratio showed that subjects with schizophrenia were increased risk of VDD 2.03 times and 2.43 times of VDI compared to controls. Four studies included in this meta-analysis discussed the sex difference of Vit D between schizophrenia and healthy subjects. Three of them reported female have higher serum Vit D concentration than male[44, 59,69], only one was the opposite[73]. Evidence have provided a sex difference in the risk of developing schizophrenia[25, 26], while Saha's meta-analysis found no significant difference between female and male[27].

This evidence synthesis suggests that schizophrenic patients have lower Vit D level compare with healthy adults and other psychiatric patients. However, Vit D level is often low even among healthy adults, with the prevalence of Vit D deficiency decreased from $30 \%$ to $20 \%$ of healthy Iranian adults aged 35 years and older approximately in 2001 to 2013 [78]. As we know, the vitamin D endocrine system plays a primary role in the maintenance of extracellular fluid calcium concentration. Vitamin D deficiency was associated with bone disease and many other conditions such as cardiovascular disease, respiratory disease, gastrointestinal disease, neurological disease and so on [79]. The relationship between vitamin D and schizophrenia has aroused great concern between 
human being. Epidemiological studies observed that in individuals born in winter or spring, an area in high latitude has a slight but significant increased risk for schizophrenia $[16,80,81]$. Due to exposure to sunlight and the serum level of vitamin D play an essential role in it.

In observational studies, one of the primary sources of bias is confounding. In this study, confounders possibly due to differences in sample sizes, a tool of diagnosis, severity or stage of the disease, matching between cases and controls and causal environmental factors, and so on. Analysis of subgroup on country, quality of study and hospitalization status demonstrated there were no significant differences between subgroups. Study design, age and outcome might be part of the source of heterogeneity. Three studies even have a opposite conclusion compared with the others[39, 41, 74].

Schizophrenia is a heterogeneous disorder in which there is interaction between genetic and environmental factors. The environmental factors include the date of birth, place of birth and seasonal effects, infectious diseases, complications during pregnancy and delivery, substance abuse, stress and nutritional deficiencies (e.g., famine, folic acid, iron, vitamin D) [82-84]. Previous literature[85, 86] has described older age and dark skin as potential risk factors associated with vitamin D deficiency. Because of these factors, different concentration of Vit D between studies might be the source of heterogeneity.

In the database, our results of meta-analysis were similar to a previous paper in this regard excepted we did a relationship of gender and included some new studies [22]. For sex differences in the risk of a particular disorder can yield important clues regarding its pathogenesis and evidence for a sex difference in the risk of schizophrenia is inconclusive. Compared to this article, we have a more stringent inclusion strategy and data was unified with a standard algorithm.

At the same time, the limitations of our study should be considered. Firstly, all of the studies were observational study, and the quality of literature is relatively general. Secondly, all of the studies included in the literature and published by the database had some publication bias. Size of the sample and the results of studies could affect the publication bias. Finally, due to the lack of sufficient information about patients' sex and age, we were unable to conduct subgroup analysis according to these included studies. Therefore, it is uncertain whether these discrepancies may influence the result to a certain extent and the results should be interpreted with caution.

\section{Abbreviations}

Vit D: vitamin D; 25(OH)D: 25-hydroxyvitamin D; VDD: vitamin D deficiency; VDI: vitamin D insufficiency; AHRQ: Agency for Healthcare Research and Quality; MD: mean difference; RD: risk difference; 95\% Cl: 95\% confidence interval; SE: standard error; OR: odds ratio; WMD: weighted mean difference; SZ, schizophrenia; C, control; VD, Vitamin D; VDD, Vitamin D deficient; VDI, Vitamin D insufficient; IA, Immunoassay; RIA, Radioimmunoassay; CLIA, Chemiluminescence immunoassay; RLM, Routine laboratory methods; El, Electroluminescence; LC-MS/MS, Liquid chromatography-tandem mass spectrometry; NM, not mentioned; ELFA, Enzyme-linked fluorescent immunoassay; T, total; SZ, schizophrenia; CLIA, Chemiluminescence immunoassay; ECLIA: electrochemiluminescence immunoassay; RIA, Radioimmunoassay; RDM: the Roche Diagnostic method

\section{Declarations}

\section{Acknowledgments}

Not applicable.

\section{Authors' contributions}

Conceptualization: WXP, JLZ. Data curation: JLZ, WWL, XC, YL. Formal analysis: JLZ, WWL. Investigation: QZZ, XC, YL, JLZ. Methodology: QZZ, WXP. Project administration: WXP. Software: JLZ, XC, YL. Writing-original draft: JLZ, WWL. Writing-review and editing: WXP, QZZ. All authors have read and approved the manuscript.

\section{Author's information}

All researchers in the study were trained regarding the protocol and Good Clinical Practice guidelines.

1 Department of Pharmacy, the Second Xiangya Hospital, Central South University, Changsha, Hunan 410011, China;

2 Institute of Clinical Pharmacy, Central South University, Changsha, Hunan 410011, China

\section{Funding}

There was no funding source.

\section{Availability of data and materials}

Data are available from the first and the corresponding authors.

\section{Ethics approval and consent to participate}

Not applicable.

\section{Consent for publication}

Not applicable. 
The authors declare that they have no competing interests.

\section{References}

1. Wacker M, Holick MF: Vitamin D-Effects on Skeletal and Extraskeletal Health and the Need for Supplementation. Nutrients 2013, 5(1):111-148.

2. Kesby JP, Eyles DW, Burne THJ, McGrath JJ: The effects of vitamin D on brain development and adult brain function. Molecular and Cellular Endocrinology 2011, 347(1-2):121-127.

3. Holick MF: Vitamin D deficiency. N Engl J Med 2007, 357(3):266-281.

4. Ebers GC, Sadovnick AD, Veith R: Vitamin D intake and incidence of multiple sclerosis. Neurology 2004, 63(5):939-939.

5. Kocovska E, Gaughran F, Krivoy A, Meier U-C: Vitamin-D Deficiency As a Potential Environmental Risk Factor in Multiple Sclerosis, Schizophrenia, and Autism. Frontiers in Psychiatry 2017, 8.

6. Cui X, Gooch H, Groves NJ, Sah P, Burne TH, Eyles DW, McGrath JJ: Vitamin D and the brain: key questions for future research. The Journal of steroid biochemistry and molecular biology 2015, 148:305-309.

7. Belvederi Murri M, Respino M, Masotti M, Innamorati M, Mondelli V, Pariante C, Amore M: Vitamin D and psychosis: mini meta-analysis. Schizophr Res 2013, 150(1):235-239.

8. Berg AO, Psychol C, Melle I, Torjesen PA, Lien L, Hauff E, Andreassen OA: A Cross-Sectional Study of Vitamin D Deficiency Among Immigrants and Norwegians With Psychosis Compared to the General Population. Journal of Clinical Psychiatry 2010, 71(12):1598-1604.

9. McGrath JJ, Burne TH, Feron F, Mackay-Sim A, Eyles DW: Developmental Vitamin D Deficiency and Risk of Schizophrenia: A 10-Year Update. Schizophrenia Bulletin 2010, 36(6):1073-1078.

10. Tandon R, Nasrallah HA, Keshavan MS: Schizophrenia, "just the facts" 4. Clinical features and conceptualization. Schizophr Res 2009, 110(1-3):1-23.

11. Yamada K: Translational Research in Neurodevelopmental Disorders: Development of Etiology-Based Animal Models Foreword. Biol Pharm Bull 2011, 34(9):1357-1357.

12. McGrath J, Saha S, Chant D, Welham J: Schizophrenia: A Concise Overview of Incidence, Prevalence, and Mortality. Epidemiol Rev 2008, 30(1):67-76.

13. Charlson FJ, Ferrari AJ, Santomauro DF, Diminic S, Stockings E, Scott JG, McGrath JJ, Whiteford HA: Global Epidemiology and Burden of Schizophrenia: Findings From the Global Burden of Disease Study 2016. Schizophrenia bulletin 2018, 44(6):1195-1203.

14. Miller CL: Evidence for phenotypic plasticity in response to photic cues and the connection with genes of risk in schizophrenia. Frontiers in Behavioral Neuroscience 2013, 7.

15. Wang C, Zhang Y: Season of birth and schizophrenia: Evidence from China. Psychiatry Research 2017, 253:189-196.

16. Davies G, Welham J, Chant D, Torrey EF, McGrath J: A systematic review and meta-analysis of Northem Hemisphere season of birth studies in schizophrenia. Schizophrenia Bulletin 2003, 29(3):587-593.

17. Kinney DK, Teixeira P, Hsu D, Napoleon SC, Crowley DJ, Miller A, Hyman W, Huang E: Relation of schizophrenia prevalence to latitude, climate, fish consumption, infant mortality, and skin color: a role for prenatal vitamin d deficiency and infections? Schizophr Bull 2009, 35(3):582-595.

18. Firth J, Carney R, Teasdale S, Stubbs B, Ward P, Berk M, Sarris J: Nutritional Deficiencies and Clinical Correlates in First-Episode Psychosis: A Systematic Review and Meta-Analysis. Schizophrenia Bulletin 2018, 44:S405-S405.

19. Crews M, Lally J, Gardner-Sood P, Howes O, Bonaccorso S, Smith S, Murray RM, Di Forti M, Gaughran F: Vitamin D deficiency in first episode psychosis: A case-control study. Schizophrenia Research 2013, 150(2-3):533-537.

20. McGrath JJ, Eyles DW, Pedersen CB, Anderson C, Ko P, Burne TH, Norgaard-Pedersen B, Hougaard DM, Mortensen PB: Neonatal Vitamin D Status and Risk of Schizophrenia A Population-Based Case-Control Study. Archives of General Psychiatry 2010, 67(9):889-894.

21. Eserian JK, Kalleian EA: Association between vitamin D levels and schizophrenia: Epidemiological and preclinical evidences. Revista Neurociencias 2013, 21(3):461-467.

22. Valipour G, Saneei P, Esmaillzadeh A: Serum Vitamin D Levels in Relation to Schizophrenia: A Systematic Review and Meta-Analysis of Observational Studies. Journal of Clinical Endocrinology \& Metabolism 2014, 99(10):3863-3872.

23. McGrath J, Saari K, Hakko H, Jokelainen J, Jones P, Järvelin MR, Chant D, Isohanni M: Vitamin D supplementation during the first year of life and risk of schizophrenia: A Finnish birth cohort study. Schizophrenia Research 2004, 67(2-3):237-245.

24. Norelli LJ, Coates AD, Kovasznay BM: A comparison of 25-hydroxyvitamin D serum levels in acute and long-stay psychiatric inpatients: A preliminary investigation. e-SPEN2010, 5(4):e187-e189.

25. Aleman A, Kahn RS, Selten JP: Sex differences in the risk of schizophrenia - Evidence from meta-analysis. Archives of General Psychiatry 2003, 60(6):565571.

26. McGrath J, Saha S, Welham J, El Saadi O, MacCauley C, Chant D: A systematic review of the incidence of schizophrenia: the distribution of rates and the influence of sex, urbanicity, migrant status and methodology. Bmc Medicine 2004, 2.

27. Saha S, Chant D, Welham J, McGrath J: A systematic review of the prevalence of schizophrenia. Plos Med 2005, 2(5):413-433.

28. Kishimoto T, Watanabe K, Shimada N, Makita K, Yagi G, Kashima H: Antipsychotic-induced hyperprolactinemia inhibits the hypothalamo-pituitary-gonadal axis and reduces bone mineral density in male patients with schizophrenia Journal of Clinical Psychiatry 2008, 69(3):385-391. 
29. Nefzi R, Larnaout A, Ammar HB, Khelifa E, Aissa A, El Hechmi Z: Hypovitaminosis D in schizophrenia: Prevalence and associated clinical characteristics. Schizophrenia Bulletin 2018, 44:S403.

30. Shukurova M, Yuksek E, Emul M, Savrun M: Vitamin D level in schizophrenia and association with metabolic syndrome parameters. Klinik Psikofarmakoloji Bulteni 2015, 25:S29-S30.

31. Hummer M, Malik P, Gasser RW, Hofer A, Kemmler G, Moncayo Naveda RC, Rettenbacher MA, Fleischhacker WW: Osteoporosis in patients with schizophrenia. Am J Psychiatry 2005, 162(1):162-167.

32. Wyszogrodzka-Kucharska A, Rabe-Jablonska J: Vitamin D deficiency and impaired parathormone metabolism as a risk factor of low bone mineral density in patients with diagnosis of schizophrenia treated with second generation antipsychotics. European Neuropsychopharmacology 2006, 16:S373-S374.

33. Boerman R, Cohen D, Schulte PF: Do Vitamin D Levels in Bipolar and Schizophenia Outpatients Differ? Outcome of a Dutch Cross-Sectional Study. European Psychiatry 2013, 28.

34. Rylander M, Verhulst S: Vitamin D Insufficiency in Psychiatric Inpatients. Journal of Psychiatric Practice 2013, 19(4):296-300.

35. Yoo T, Choi W, Hong JH, Lee JY, Kim JM, Shin IS, Yang SJ, Amminger P, Berk M, Yoon JS et al: Association Between Vitamin D Insufficiency and Metabolic Syndrome in Patients With Psychotic Disorders. Psychiatry Investig 2018, 15(4):396-401.

36. Agarwal SK: High Incidence of Vitamin D Deficiency in Patients with Schizophrenia. European Psychiatry $2013,28$.

37. Agarwal SK: Hypovitaminosis D and hypotestosteronemia in schizophrenia patients European Psychiatry $2013,28$.

38. Akbar NL, Effendy E, Amin M: Vitamin D and plain type: a study of male patients with schizophrenia. In: 1 st Int Conf on Trop Med \& Infect Dis Fac of Med Univ Sumatera Utara in Conjunction with the 23rd Natl Congress of the Indonesian Soc of Trop \& Infect Dis Consultant and the 18th Annual Meeting of Internal Med Dept Fac of Med Univ Sumatera Utara. Volume 125, edn. Edited by Baird K, DeJong M, Widodo D, Manosuthi W, Wijaya L, Eyanoer PC, Zein U; 2018.

39. Yuksel RN, Altunsoy N, Tikir B, Cingi Kuluk M, Unal K, Goka S, Aydemir C, Goka E: Correlation between total vitamin D levels and psychotic psychopathology in patients with schizophrenia: therapeutic implications for add-on vitamin D augmentation. Therapeutic advances in psychopharmacology 2014, 4(6):268-275.

40. Humble MB, Gustafsson S, Bejerot S: Low serum levels of 25-hydroxyvitamin D (25-OHD) among psychiatric out-patients in Sweden: Relations with season, age, ethnic origin and psychiatric diagnosis. Journal of Steroid Biochemistry and Molecular Biology 2010, 121(1-2):467-470.

41. Abdullah AK, Khan S, Mustafa SF, Qutubuddin AA, Davis CM: Vitamin D status and cardiometabolic risk factors in long-term psychiatric inpatients. Primary Care Companion to the Journal of Clinical Psychiatry 2012, 14(1).

42. Hozo SP, Djulbegovic B, Hozo I: Estimating the mean and variance from the median, range, and the size of a sample. $B M C$ medical research methodology 2005, 5:13-13.

43. Partti K, Heliovaara M, Impivaara O, Perala J, Saarni SI, Lonnqvist J, Suvisaari JM: Skeletal Status in Psychotic Disorders: A Population-Based Study. Psychosomatic Medicine 2010, 72(9):933-940.

44. Rey-Sánchez P, Lavado-García JM, Canal-Macías ML, Gómez-Zubeldia M, Roncero-Martín R, Pedrera-Zamorano JD: Ultrasound bone mass in schizophrenic patients on antipsychotic therapy. Human Psychopharmacology 2009, 24(1):49-54.

45. Bouillon R, Norman AW, Lips P: Vitamin D deficiency. New England Journal of Medicine 2007, 357(19):1980-1981.

46. Stang AJEJoE: Critical evaluation of the Newcastle-Ottawa scale for the assessment of the quality of nonrandomized studies in meta-analyses. 2010, 25(9):603-605.

47. Hu J, Dong Y, Chen X, Liu Y, Ma D, Liu X, Zheng R, Mao X, Chen T, He W: Prevalence of suicide attempts among Chinese adolescents: A meta-analysis of cross-sectional studies. Comprehensive Psychiatry 2015, 61:78-89.

48. Higuchi T, Komoda T, Sugishita M, Yamazaki J, Miura M, Sakagishi Y, Yamauchi T: Certain neuroleptics reduce bone mineralization in schizophrenic patients. Neuropsychobiology 1987, 18(4):185-188.

49. Cha B, Shin YM, Kim YS, Kim BJ, Lee CS, Sohn JW, Park CS: Vitamin D deficiency in schizophrenia, bipolar disorder and major depressive disorder compared to healthy controls. European Neuropsychopharmacology 2011, 21:S429-S430.

50. Grados D, Salavert J, Ramiro N, Carrión M, Ramírez N, Erra A: Is there a relationship between vitamin d and schizophrenia? Annals of the Rheumatic Diseases 2015, 74:1198.

51. Bogers JPAM, Bostoen T, Broekman TG: Low levels of vitamin D poorly responsive to daylight exposure in patients with therapy-resistant schizophrenia. Nordic Journal of Psychiatry 2016, 70(4):262-266.

52. Kulaksizoglu S, Kulaksizoglu B: The Relationship between Metabolic Syndrome, BDNF, and Vitamin D in Patients with Schizophrenia. Neurochemical Journal 2017, 11(1):104-111.

53. Schneider B, Weber B, Frensch A, Stein J, Fritz J: Vitamin D in schizophrenia, major depression and alcoholism. Journal of neural transmission (Vienna, Austria : 1996) 2000, 107(7):839-842.

54. Bergemann N, Parzer P, Mundt C, Auler B: High bone tumover but normal bone mineral density in women suffering from schizophrenia. Psychological Medicine 2008, 38(8):1195-1201.

55. Doknic M, Maric NP, Britvic D, Pekic S, Damjanovic A, Miljic D, Stojanovic M, Radojicic Z, Gasic MJ, Popovic V: Bone Remodeling, Bone Mass and Weight Gain in Patients with Stabilized Schizophrenia in Real-Life Conditions Treated with Long-Acting Injectable Risperidone. Neuroendocrinology 2011, 94(3):246-254.

56. Itzhaky D, Amital D, Gorden K, Bogomolni A, Arnson Y, Amital H: Low Serum Vitamin D Concentrations in Patients with Schizophrenia. Israel Medical Association Journal 2012, 14(2):88-92. 
57. Jamilian H, Bagherzadeh K, Nazeri Z, Hassanijirdehi M: Vitamin D, parathyroid hormone, serum calcium and phosphorus in patients with schizophrenia and major depression. International Journal of Psychiatry in Clinical Practice 2013, 17(1):30-34.

58. Clelland JD, Read LL, Drouet V, Kaon A, Kelly A, Duff KE, Nadrich RH, Rajparia A, Clelland CL: Vitamin D insufficiency and schizophrenia risk: Evaluation of hyperprolinemia as a mediator of association. Schizophrenia Research 2014, 156(1):15-22.

59. Graham KA, Keefe RS, Lieberman JA, Calikoglu AS, Lansing KM, Perkins DO: Relationship of low vitamin D status with positive, negative and cognitive symptom domains in people with firstepisode schizophrenia. Early Intervention in Psychiatry 2015, 9(5):397-405.

60. Zhu D-m, Liu Y, Zhang A-g, Chu Z-x, Wu Q, Li H, Ge J-f, Dong Y, Zhu P: High levels of vitamin D in relation to reduced risk of schizophrenia with elevated Creactive protein. Psychiatry Research 2015, 228(3):565-570.

61. Bulut SD, Bulut S, Atalan DG, Berkol T, Gurcay E, Turker T, Aydemir C: The Relationship between Symptom Severity and Low Vitamin D Levels in Patients with Schizophrenia. Plos One 2016, 11(10).

62. Endres D, Dersch R, Stich O, Buchwald A, Perlov E, Feige B, Maier S, Riedel A, van Elst LT: Vitamin D Deficiency in Adult Patients with Schizophreniform and Autism Spectrum Syndromes: A One-Year Cohort Study at a German Tertiary Care Hospital. Frontiers in Psychiatry 2016, 7.

63. Akinlade KS, Olaniyan OA, Lasebikan VO, Rahamon SK: Vitamin D levels in Different severity groups of schizophrenia. Frontiers in Psychiatry $2017,8$.

64. Salavert J, Grados D, Ramiro N, Carrion MI, Fadeuilhe C, Palma F, Lopez L, Erra A, Ramirez N: Association Between Vitamin D Status and Schizophrenia A First Psychotic Episode Study. Journal of Nervous and Mental Disease 2017, 205(5):409-412.

65. Bazzano AN, Littrell L, Lambert S, Roi C: Factors associated with vitamin D status of low-income, hospitalized psychiatric patients: results of a retrospective study. Neuropsychiatric Disease and Treatment 2016, 12:2973-2980.

66. Bruins J, Jorg F, van den Heuvel ER, Bartels-Velthuis AA, Corpeleijn E, Muskiet FAJ, Pijnenborg GHM, Bruggeman R: The relation of vitamin D, metabolic risk and negative symptom severity in people with psychotic disorders. Schizophrenia Research 2018, 195:513-518.

67. Menkes DB, Lancaster K, Grant M, Marsh RW, Dean P, du Toit SA: Vitamin D status of psychiatric inpatients in New Zealand's Waikato region. Bmc Psychiatry 2012, 12.

68. Murie J, Messow C-M, Fitzpatrick B: Feasibility of screening for and treating vitamin D deficiency in forensic psychiatric inpatients. Journal of Forensic and Legal Medicine 2012, 19(8):457-464.

69. Cieslak K, Feingold J, Antonius D, Walsh-Messinger J, Dracxler R, Rosedale M, Aujero N, Keefe D, Goetz D, Goetz R et al: Low Vitamin D levels predict clinical features of schizophrenia. Schizophrenia Research 2014 159(2-3):543-545.

70. Boerman R, Cohen D, Schulte PFJ, Nugter A: Prevalence of Vitamin D Deficiency in Adult Outpatients With Bipolar Disorder or Schizophrenia. Journal of Clinical Psychopharmacology 2016, 36(6):588-592.

71. Lally J, Gardner-Sood P, Firdosi M, Iyegbe C, Stubbs B, Greenwood K, Murray R, Smith S, Howes O, Gaughran F: Clinical correlates of vitamin D deficiency in established psychosis. Bmc Psychiatry 2016, 16.

72. Ikonen H, Palaniswamy S, Nordstrom T, Jarvelin MR, Herzig KH, Jaaskelainen E, Seppala J, Miettunen J, Sebert S: Vitamin D status and correlates of low vitamin D in schizophrenia, other psychoses and non-psychotic depression - The Northern Finland Birth Cohort 1966 study. Psychiatry Research 2019 , 279:186-194.

73. Yazici AB, Ciner OA, Yazici E, Cilli AS, Dogan B, Erol A: Comparison of vitamin B12, vitamin D and folic acid blood levels in patients with schizophrenia, drug addiction and controls. Journal of Clinical Neuroscience 2019, 65:11-16.

74. Yazici E, Pek TM, Guzel D, Yazici AB, Ciner OA, Erol A: Klotho, vitamin D and homocysteine levels during acute episode and remission periods in schizophrenia patients. Nordic Journal of Psychiatry 2019, 73(3):178-184.

75. Patel D, Minajagi M: Prevalence of vitamin D deficiency in adult patients admitted to a psychiatric hospital. Bjpsych Bulletin 2018, 42(3):123-126.

76. Zoghbi M, Haddad C, Hallit S, Nabout R, Medlej-Hashim M, Hachem D, Azar J: Cognition and physical functioning in patients with schizophrenia: any role for vitamin D? Nutritional neuroscience 2019:1-9.

77. Malik BR, Zafar MH, Khan S: Role of Vitamin D as Adjuvant Therapy of Hypovitaminosis D in Patients of Schizophrenia. Pakistan Journal of Medical \& Health Sciences 2019, 13(1):303-305.

78. Khosravi-Boroujeni H, Sarrafzadegan N, Sadeghi M, Roohafza H, Ng SK, Pourmogaddas A, Ahmed F: Prevalence and Trends of Vitamin D Deficiency among Iranian Adults: A Longitudinal Study from 2001-2013. J Nutr Sci Vitaminol (Tokyo) 2017, 63(5):284-290.

79. Sahota O: Understanding vitamin D deficiency. Age and ageing 2014, 43(5):589-591.

80. McGrath JJ: The surprisingly rich contours of schizophrenia epidemiology. Archives of General Psychiatry 2007, 64(1):14-16.

81. Torrey EF, Miller J, Rawlings R, Yolken RH: Seasonality of births in schizophrenia and bipolar disorder: a review of the literature. Schizophrenia research 1997, 28(1):1-38.

82. Janoutova J, Janackova P, Sery O, Zeman T, Ambroz P, Kovalova M, Varechova K, Hosak L, Jirik V, Janout V: Epidemiology and risk factors of schizophrenia. Neuroendocrinology Letters 2016, 37(1):1-8.

83. Brown AS: The environment and susceptibility to schizophrenia. Prog Neurobiol 2011, 93(1):23-58.

84. Sarris J, Logan AC, Akbaraly TN, Amminger GP, Balanza-Martinez V, Freeman MP, Hibbeln J, Matsuoka Y, Mischoulon D, Mizoue T et al: Nutritional medicine as mainstream in psychiatry. Lancet Psychiat 2015, 2(3):271-274.

85. Ford ES, Ajani UA, McGuire LC, Liu S: Concentrations of serum vitamin D and the metabolic syndrome among US adults. Diabetes Care 2005, 28(5):12281230. 
Tables

Table 1 Baseline Characteristics for Case-control Studies included in Meta-analysis

\begin{tabular}{|c|c|c|c|c|c|c|c|c|c|c|c|c|c|}
\hline \multirow[t]{2}{*}{ Study ID } & \multicolumn{2}{|c|}{$\begin{array}{c}\text { Number of Cases } \\
(\% \text { male })\end{array}$} & \multirow{2}{*}{$\begin{array}{l}\text { Age } \\
\text { (mean } \\
\text { or } \\
\text { range) }\end{array}$} & \multirow{2}{*}{$\begin{array}{l}\text { in/out } \\
\text { patient }\end{array}$} & \multirow[t]{2}{*}{$\begin{array}{l}\text { Diagnosis } \\
\text { tool }\end{array}$} & \multirow{2}{*}{$\begin{array}{l}\text { Ethnicity } \\
\text { or } \\
\text { Country }\end{array}$} & \multirow[t]{2}{*}{ Outcomes } & \multirow[t]{2}{*}{$\begin{array}{l}\text { Measurement } \\
\text { of VD }\end{array}$} & \multirow{2}{*}{$\begin{array}{l}\text { Categories of } \\
\text { VDD and VDI } \\
(\mathrm{ng} / \mathrm{ml})\end{array}$} & \multicolumn{2}{|c|}{ VDD or VDI } & \multicolumn{2}{|c|}{ Mean level of VD (ng } \\
\hline & SZ & $\mathrm{C}$ & & & & & & & & SZ & $\mathrm{C}$ & SZ & C \\
\hline Higuchi & $12(42 \%)$ & $5(100 \%)$ & $18-57$ & in & & Japan & $25(\mathrm{OH}) \mathrm{D} 3$ & HPLC & & & & $12.6 \pm 2.2$ & 22.3: \\
\hline-1987 & & & & & & & & & & & & & \\
\hline $\begin{array}{c}\text { Schneider- } \\
2000\end{array}$ & $34(56 \%)$ & $31(61 \%)$ & $21-81$ & in & $\begin{array}{c}\text { DSM-III- } \\
\text { R }\end{array}$ & Germany & 25(OH)D3 & IA & & & & $35.1 \pm 26.1$ & $45.9 \pm$ \\
\hline $\begin{array}{l}\text { Bergemann- } \\
2008\end{array}$ & $72(0 \%)$ & $71(0 \%)$ & $20-46$ & in & $\begin{array}{l}\text { DSM-IV } \\
\text { ICD-10 }\end{array}$ & Germany & $25(\mathrm{OH}) \mathrm{D}$ & & & & & $16.3 \pm 7.9$ & $24.6 \pm$ \\
\hline $\begin{array}{l}\text { Rey-Sánchez- } \\
2009\end{array}$ & $73(66 \%)$ & $73(66 \%)$ & 61 & in & $\begin{array}{l}\text { DSM-IV } \\
\text { CIE-10 }\end{array}$ & Spain & $25(\mathrm{OH}) \mathrm{D} 3$ & RIA & deficient: $<15$ & $\begin{array}{l}\text { F:19 } \\
\text { M:33 }\end{array}$ & & $\begin{array}{l}F: 20.42 \pm 26.05 \\
\text { M:15.12 } \pm 11.96\end{array}$ & $\begin{array}{l}\text { F:33.12 } \\
\text { M:18.13 }\end{array}$ \\
\hline Norelli-2010 & 40 & 20 & $18-65$ & in & DSM-IV & $\begin{array}{l}\text { White } \\
\text { Black }\end{array}$ & $25(\mathrm{OH}) \mathrm{D}$ & & $\begin{array}{l}\text { deficient: }<20 \\
\text { insufficient: } \\
<30\end{array}$ & $\begin{array}{l}23 \\
33\end{array}$ & $\begin{array}{c}9 \\
16\end{array}$ & $19.5 \pm 9.3$ & $22.7 \pm$ \\
\hline Cha-2011 & 14 & 32 & & & DSM-IV & $\begin{array}{l}\text { South } \\
\text { Korea }\end{array}$ & $25(\mathrm{OH}) \mathrm{D}$ & RIA & $\begin{array}{c}\text { deficient: }<20 \\
\text { insufficient: } \\
<30\end{array}$ & $\begin{array}{l}2 \\
5\end{array}$ & $\begin{array}{l}0 \\
1\end{array}$ & & \\
\hline Doknic-2011 & $26(46 \%)$ & $35(31 \%)$ & 32 & out & DSM-IV & Serbia & $25(\mathrm{OH}) \mathrm{D}$ & CLIA & & & & $9.22 \pm 1.12$ & 28.76: \\
\hline $\begin{array}{l}\text { Jamilian- } \\
2013\end{array}$ & $100(68 \%)$ & $100(50 \%)$ & 35.5 & in & $\begin{array}{l}\text { DSM-4- } \\
\text { TR }\end{array}$ & Iran & $25(\mathrm{OH}) \mathrm{D}$ & RLM & & & & $18.8 \pm 4.56$ & $21.32:$ \\
\hline $\begin{array}{l}\text { Clelland- } \\
2014\end{array}$ & $64(48 \%)$ & $90(49 \%)$ & $18-65$ & in & DSM IV & $\begin{array}{l}\text { African- } \\
\text { American } \\
\text { Caucasian } \\
\text { Hispanic }\end{array}$ & $25(\mathrm{OH}) \mathrm{D}$ & CLIA & $\begin{array}{l}\text { insufficient: } \\
\quad<30\end{array}$ & 44 & 42 & $31.63 \pm 22.64$ & $37.06:$ \\
\hline Bogers-2016 & 80 & 29 & 42 & both & & $\begin{array}{c}\text { Caucasian } \\
\text { non- } \\
\text { Caucasian }\end{array}$ & 25(OH)D3 & & deficient: $<20$ & 63 & 17 & & \\
\hline Itzhaky-2012 & $50(68 \%)$ & $50(26 \%)$ & $19-65$ & in & PANSS & Israel & $25(\mathrm{OH}) \mathrm{D}$ & CLIA & $\begin{array}{l}\text { deficient: }<15 \\
\text { insufficient: } \\
<30\end{array}$ & $\begin{array}{l}28 \\
20\end{array}$ & $\begin{array}{l}12 \\
31\end{array}$ & $15.0 \pm 7.3$ & 20.2: \\
\hline Yuksel-2014 & $81(58 \%)$ & $40(48 \%)$ & $18-65$ & $\begin{array}{l}\text { out } \\
\text { in }\end{array}$ & $\begin{array}{l}\text { DSM-IV- } \\
\text { TR }\end{array}$ & $\begin{array}{l}\text { Turkish } \\
\text { Kurdish } \\
\text { Other }\end{array}$ & $25(\mathrm{OH}) \mathrm{D}$ & EI & $\begin{array}{c}\text { deficient: }<10 \\
\text { insufficient: } \\
<20\end{array}$ & $\begin{array}{l}35 \\
40\end{array}$ & $\begin{array}{l}12 \\
22\end{array}$ & $\begin{array}{c}7.92 \pm 2.89 \\
14.99 \pm 4.89\end{array}$ & 14.94: \\
\hline Grados-2015 & 13 & 17 & & In & NM & Spain & $25(\mathrm{OH}) \mathrm{D}$ & CLIA & $\begin{array}{c}\text { deficient: }<20 \\
\text { insufficient: } \\
<30\end{array}$ & & & $12.87 \pm 17.2$ & 21.45 : \\
\hline Graham-2015 & $20(60 \%)$ & $20(60 \%)$ & $17-33$ & Out & SCID & $\begin{array}{l}\text { Caucasian } \\
\text { African- } \\
\text { American }\end{array}$ & $25(\mathrm{OH}) \mathrm{D}$ & CLIA & deficient: $<30$ & 11 & & $28.2 \pm 12.6$ & $29.9 \pm$ \\
\hline Zhu-2015 & 93(44\%) & $93(56 \%)$ & $18-65$ & out & DSM-IV & Yellow & $25(\mathrm{OH}) \mathrm{D}$ & RIA & & & & $10.55 \pm 5.32$ & 17.48: \\
\hline Bulut-2016 & $80(53 \%)$ & $74(53 \%)$ & $18-55$ & out & $\begin{array}{l}\text { DSM-IV } \\
\text { TR }\end{array}$ & Turkey & $25(\mathrm{OH}) \mathrm{D}$ & EI & $\begin{array}{c}\text { deficient: }<10 \\
\text { insufficient: } \\
<20\end{array}$ & $\begin{array}{l}20 \\
11\end{array}$ & $\begin{array}{c}6 \\
21\end{array}$ & $23.46 \pm 13.98$ & 23.69: \\
\hline Endres-2016 & $60(58 \%)$ & $3917(44 \%)$ & $18-79$ & in & ICD-10 & Germany & $25(\mathrm{OH}) \mathrm{D}$ & CLIA & $\begin{array}{l}\text { deficient: }<20 \\
\text { insufficient: } \\
\quad<30 \\
\text { sufficient: }>30\end{array}$ & $\begin{array}{c}48 \\
9 \\
3\end{array}$ & $\begin{array}{l}2244 \\
815 \\
858\end{array}$ & $15.0 \pm 9.8$ & $18 \pm$ \\
\hline $\begin{array}{l}\text { Akinlade- } \\
2017\end{array}$ & 60 & 30 & $19-55$ & in & $\begin{array}{l}\text { DSM-IV } \\
\text { ICD-10 }\end{array}$ & Ibadan & $25(\mathrm{OH}) \mathrm{D}$ & ELISA & $\begin{array}{l}\text { deficient: }<20 \\
\text { insufficient: } \\
<30\end{array}$ & $\begin{array}{l}35 \\
24\end{array}$ & $\begin{array}{c}2 \\
17\end{array}$ & $19.75 \pm 5.19$ & 28.06: \\
\hline $\begin{array}{c}\text { Kulaksizoglu- } \\
2017\end{array}$ & $64(56 \%)$ & $54(57 \%)$ & $18-65$ & out & $\begin{array}{l}\text { DSM-IV- } \\
\text { TR }\end{array}$ & Turkey & $25(\mathrm{OH}) \mathrm{D}$ & CLIA & & & & $10.06 \pm 2.64$ & 10.86: \\
\hline $\begin{array}{l}\text { Salavert- } \\
2017\end{array}$ & $22(73 \%)$ & $22(27 \%)$ & $18-65$ & in & DSM-IV & European & $25(\mathrm{OH}) \mathrm{D}$ & CLIA & deficient: $<20$ & 19 & 8 & $13.14 \pm 5.96$ & 22.63: \\
\hline Ikonen-2019 & $40(55 \%)$ & $4659(50 \%)$ & 31 & both & ICD-10 & Finland & $25(\mathrm{OH}) \mathrm{D}$ & HPLC-MS & $\begin{array}{c}\text { deficient: }<12 \\
\text { insufficient: } \\
<20 \\
\text { sufficient: }>20\end{array}$ & $\begin{array}{c}1 \\
11 \\
28\end{array}$ & $\begin{array}{c}149 \\
1172 \\
3338\end{array}$ & $26.2 \pm 4.44$ & $27.3 \pm$ \\
\hline $\begin{array}{l}\text { Yazici, AB- } \\
2019\end{array}$ & 189 & 109 & 41.4 & in & DSM- $-\square$ & Turkey & $25(\mathrm{OH}) \mathrm{D}$ & ELFA & $\begin{array}{c}\text { deficient: }<20 \\
\text { insufficient: } \\
<30 \\
\text { sufficient: }>30\end{array}$ & $\begin{array}{l}126 \\
41 \\
22\end{array}$ & $\begin{array}{l}56 \\
38 \\
15\end{array}$ & $\begin{array}{c}\text { F:15.44 } \pm 8.8 \\
\text { M:19.41 } \\
17.52 \pm 9.65\end{array}$ & $\begin{array}{r}F: 17.7 \varepsilon \\
\text { M:23.97 } \\
21.26:\end{array}$ \\
\hline $\begin{array}{l}\text { Yazici, E- } \\
2019\end{array}$ & $\begin{array}{l}\text { in:30 } \\
\text { Out:30 }\end{array}$ & 28 & $19-65$ & both & $\begin{array}{l}\text { DSM-IV } \\
\text { DSM- } \square\end{array}$ & Turkey & $25(\mathrm{OH}) \mathrm{D}$ & ELISA & & & & $\begin{array}{l}\text { in: } 16.20 \pm 17.93 \\
\text { out:11.37 } \pm 4.58\end{array}$ & 13.69: \\
\hline Malik-2019 & 80 & 40 & 39.4 & both & $\begin{array}{l}\text { DSM-IV- } \\
\text { TR }\end{array}$ & Pakistan & $25(\mathrm{OH}) \mathrm{D}$ & & $\begin{array}{c}\text { deficient: }<10 \\
\text { insufficient: } \\
<20 \\
\text { sufficient: }>20\end{array}$ & $\begin{array}{c}35 \\
29 \\
6\end{array}$ & $\begin{array}{c}12 \\
20 \\
8\end{array}$ & & \\
\hline
\end{tabular}




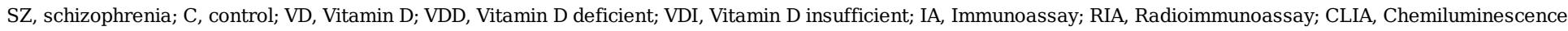

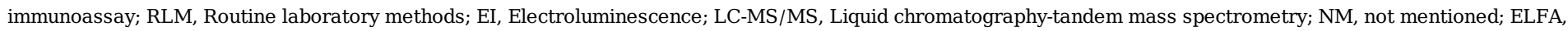
Enzyme-linked fluorescent immunoassay

Table 2 Baseline Characteristics for Cross-section studies included in Meta-analysis

\begin{tabular}{|c|c|c|c|c|c|c|c|c|c|c|c|c|c|}
\hline \multirow[t]{2}{*}{$\begin{array}{l}\text { First } \\
\text { Author }\end{array}$} & \multicolumn{2}{|c|}{$\begin{array}{c}\text { Number of Cases } \\
(\% \text { male })\end{array}$} & \multirow{2}{*}{$\begin{array}{c}\text { Age } \\
\text { (mean } \\
\text { or } \\
\text { range) }\end{array}$} & \multirow[t]{2}{*}{ in/outpatient } & \multirow[t]{2}{*}{$\begin{array}{l}\text { Diagnosis } \\
\text { tool }\end{array}$} & \multirow[t]{2}{*}{ Country } & \multirow[t]{2}{*}{ Outcomes } & \multirow[t]{2}{*}{$\begin{array}{l}\text { Measurement } \\
\text { of VD }\end{array}$} & \multirow[t]{2}{*}{$\begin{array}{l}\text { Categories of } \\
\text { VDD and VDI } \\
(\mathrm{ng} / \mathrm{ml})\end{array}$} & \multicolumn{2}{|c|}{$\begin{array}{l}\text { Number } \\
\text { of VDD or } \\
\text { VDI }\end{array}$} & \multicolumn{2}{|c|}{$\begin{array}{l}\text { Mean level of VD } \\
(\mathrm{ng} / \mathrm{ml})\end{array}$} \\
\hline & $\mathrm{C}$ & SZ & & & & & & & & $\mathrm{C}$ & $\mathrm{SZ}$ & $\mathrm{C}$ & SZ \\
\hline $\begin{array}{l}\text { Humber- } \\
2010\end{array}$ & $97(54 \%)$ & $20(40 \%)$ & 43.7 & out & ICD-10 & USA & $25(\mathrm{OH}) \mathrm{D}$ & RIA & & & & $19.7 \pm 5.9$ & $14.6 \pm 5.1$ \\
\hline $\begin{array}{l}\text { Partti- } \\
2010\end{array}$ & $6193(45 \%)$ & $48(42 \%)$ & 52.0 & out & SCID & Finland & $25(\mathrm{OH}) \mathrm{D}$ & RIA & & & & $17.5 \pm 13.2$ & $15.6 \pm 12.4$ \\
\hline $\begin{array}{l}\text { Abdullah- } \\
2012\end{array}$ & 105 & 185 & 40 & in & $\begin{array}{l}\text { ICD-9 } \\
\text { codes } \\
295\end{array}$ & $\begin{array}{c}\text { Whites } \\
\text { Non- } \\
\text { whites } \\
\text { African- } \\
\text { Americans } \\
\text { Hispanics } \\
\text { Asians }\end{array}$ & $25(\mathrm{OH}) \mathrm{D}$ & CLIA & low: $<32$ & 97 & 164 & $20.2 \pm 11.0$ & $21.2 \pm 9.4$ \\
\hline $\begin{array}{l}\text { Murie- } \\
2012\end{array}$ & 8 & 25 & $19-69$ & in & & Chinese & $25(\mathrm{OH}) \mathrm{D}$ & LC-MS/MS & $\begin{array}{l}\text { deficient: }<10 \\
\text { insufficient: } \\
<20\end{array}$ & $\begin{array}{l}5 \\
3\end{array}$ & $\begin{array}{c}14 \\
9\end{array}$ & & \\
\hline $\begin{array}{l}\text { Agarwal- } \\
2013 \text { a }\end{array}$ & & 63 & & out & & USA & $25(\mathrm{OH}) \mathrm{D}$ & & $\begin{array}{c}\text { deficient: }<10 \\
\text { insufficient: } \\
<20 \\
\text { sufficient: }<30\end{array}$ & & $\begin{array}{l}10 \\
22 \\
14\end{array}$ & & \\
\hline $\begin{array}{l}\text { Cieslak- } \\
2014\end{array}$ & & $22(59 \%)$ & & both & & USA & $25(\mathrm{OH}) \mathrm{D}$ & & $\begin{array}{c}\text { insufficient: } \\
<30\end{array}$ & & 20 & & $17.3 \pm 8.9$ \\
\hline $\begin{array}{l}\text { Bazzano- } \\
2016\end{array}$ & 52 & 61 & $18-65$ & in & & USA & $25(\mathrm{OH}) \mathrm{D}$ & & $\begin{array}{c}\text { deficient:<20 } \\
\text { insufficient: } \\
<30\end{array}$ & $\begin{array}{l}32 \\
28\end{array}$ & $\begin{array}{l}19 \\
13\end{array}$ & $23.5 \pm 10.2$ & $21.8 \pm 11.9$ \\
\hline $\begin{array}{l}\text { Boerman- } \\
2016\end{array}$ & 118 & 202 & & out & DSM-IV & Holland & $25(\mathrm{OH}) \mathrm{D}$ & CLIA & $\begin{array}{c}\text { deficient: }<12 \\
\text { insufficient: } \\
<20 \\
\text { sufficient: }<30 \\
\text { optimum: }>30\end{array}$ & $\begin{array}{l}27 \\
37 \\
30 \\
24\end{array}$ & $\begin{array}{l}70 \\
65 \\
45 \\
22\end{array}$ & $21.18 \pm 11.3$ & $17.8 \pm 11.0$ \\
\hline $\begin{array}{l}\text { Lally- } \\
2016\end{array}$ & 96 & $324(60 \%)$ & 43.8 & out & ICD-10 & $\begin{array}{l}\text { Black } \\
\text { White } \\
\text { Asian } \\
\text { Mixed }\end{array}$ & $25(\mathrm{OH}) \mathrm{D}$ & CLIA & $\begin{array}{l}\text { deficient:<10 } \\
\text { insufficient: } \\
<20\end{array}$ & & & $14.3 \pm 8.1$ & $11.5 \pm 6.7$ \\
\hline $\begin{array}{l}\text { Bruins- } \\
2018\end{array}$ & 309 & 1531 & 45 & out & & $\begin{array}{c}\text { Caucasian } \\
\text { African } \\
\text { European } \\
\text { Other }\end{array}$ & $25(\mathrm{OH}) \mathrm{D}$ & $\begin{array}{l}\text { LC-MS } \\
\text { RDM }\end{array}$ & $\begin{array}{l}\text { insufficient: } \\
<20\end{array}$ & 182 & 972 & & \\
\hline $\begin{array}{c}\text { Patel- } \\
2018\end{array}$ & 61 & 18 & $\begin{array}{l}40.6 \\
(18- \\
79)\end{array}$ & in & ICD-10 & $\begin{array}{l}\text { Black } \\
\text { White } \\
\text { Asian } \\
\text { Mixed }\end{array}$ & $25(\mathrm{OH}) \mathrm{D}$ & CLIA & $\begin{array}{c}\text { deficient: }<12 \\
\text { insufficient: } \\
<20 \\
\text { sufficient: }>20\end{array}$ & & & $13.0 \pm 13.4$ & $11.8 \pm 10.3$ \\
\hline Yoo-2018 & & $\begin{array}{c}302 \\
(56 \%)\end{array}$ & $\begin{array}{l}40.7 \\
(18- \\
82)\end{array}$ & in & & Korea & $25(\mathrm{OH}) \mathrm{D}$ & & $\begin{array}{c}\text { insufficient: } \\
\quad<20 \\
\text { sufficient:>20 }\end{array}$ & & $\begin{array}{c}236 \\
66\end{array}$ & & $15.5 \pm 6.4$ \\
\hline $\begin{array}{l}\text { Zoghbi- } \\
2019\end{array}$ & & $\begin{array}{c}196 \\
(60 \%)\end{array}$ & & & DSM- - & Lebanon & $25(\mathrm{OH}) \mathrm{D}$ & CLIA & $\begin{array}{c}\text { deficient: }<10 \\
\text { insufficient: } \\
<20 \\
\text { sufficient }>20\end{array}$ & & $\begin{array}{l}22 \\
89 \\
85\end{array}$ & & \\
\hline
\end{tabular}

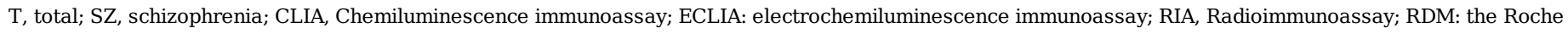
Diagnostic method 
Table 3 Subgroup analysis on mean serum level of vitamin D and schizophrenia

\begin{tabular}{|c|c|c|c|c|c|c|}
\hline Subgroup & Number of Studies & Participants, $\mathrm{n}$ & Heterogeneity $\left(\mathrm{I}^{2}\right)$ & $\mathrm{P}$ value of significance test & Subtotal $[95 \% \mathrm{CI}]$ & Subgroup difference \\
\hline Study design & 33 & 12333 & $96.1 \%$ & $P<0.01$ & $-4.50[-6.69,-2.32]$ & $P=0.11, \mathrm{I}^{2}=61.7 \%$ \\
\hline case-control & 25 & 10857 & $96.9 \%$ & $P<0.01$ & $-5.91[-7.90,-2.48]$ & \\
\hline cross-section & 8 & 1476 & $57.3 \%$ & $P=0.022$ & $-2.60[-4.20,-0.99]$ & \\
\hline Country & & & & & & $\mathrm{P}=0.23, \mathrm{I}^{2}=31.7 \%$ \\
\hline European & 14 & 10205 & $97.6 \%$ & $P=0.006$ & $-6.37[-10.88,-1.86]$ & \\
\hline Non-European & 19 & 2131 & $87.3 \%$ & $P<0.01$ & $-3.41[-5.03,-1.78]$ & \\
\hline Quality of study & & & & & & $\mathrm{P}=0.95, \mathrm{I}^{2}=0 \%$ \\
\hline High & 29 & 12089 & $96.2 \%$ & $P<0.01$ & $-4.48[-6.90,-2.06]$ & \\
\hline Low & 4 & 244 & $95.8 \%$ & $P<0.01$ & $-4.71[-11.12,1.70]$ & \\
\hline Hospitalization status & & & & & & $\mathrm{P}=0.73, \mathrm{I}^{2}=0 \%$ \\
\hline Out & 7 & 757 & $98.2 \%$ & $P<0.01$ & $-5.55[-12.39,1.28]$ & \\
\hline In & 23 & 6716 & $83.5 \%$ & $P<0.01$ & $-4.20[-5.71,-2.68]$ & \\
\hline both & 3 & 4860 & $94.2 \%$ & $P<0.01$ & $-2.70[-6.86,1.46]$ & \\
\hline Outcome & & & & & & $\mathrm{P}=0.15, \mathrm{I}^{2}=50.7 \%$ \\
\hline $25(\mathrm{OH}) \mathrm{D}$ & 28 & 12003 & $97.1 \%$ & $P<0.01$ & $-4.71[-7.60,-1.83]$ & \\
\hline $25(\mathrm{OH}) \mathrm{D} 3$ & 5 & 330 & $64.9 \%$ & $P=0.022$ & $-7.18[-10.74,-3.61]$ & \\
\hline Age & & & & & & $\mathrm{P}=0.11, \mathrm{I}^{2}=61.8 \%$ \\
\hline$<50$ & 24 & 7663 & $97.1 \%$ & $P<0.01$ & $-5.14[-7.79,-2.48]$ & \\
\hline$>50$ & 9 & 4674 & $0.0 \%$ & $P=0.52$ & $-2.71[-3.97,-1.45]$ & \\
\hline
\end{tabular}

\section{Figures}

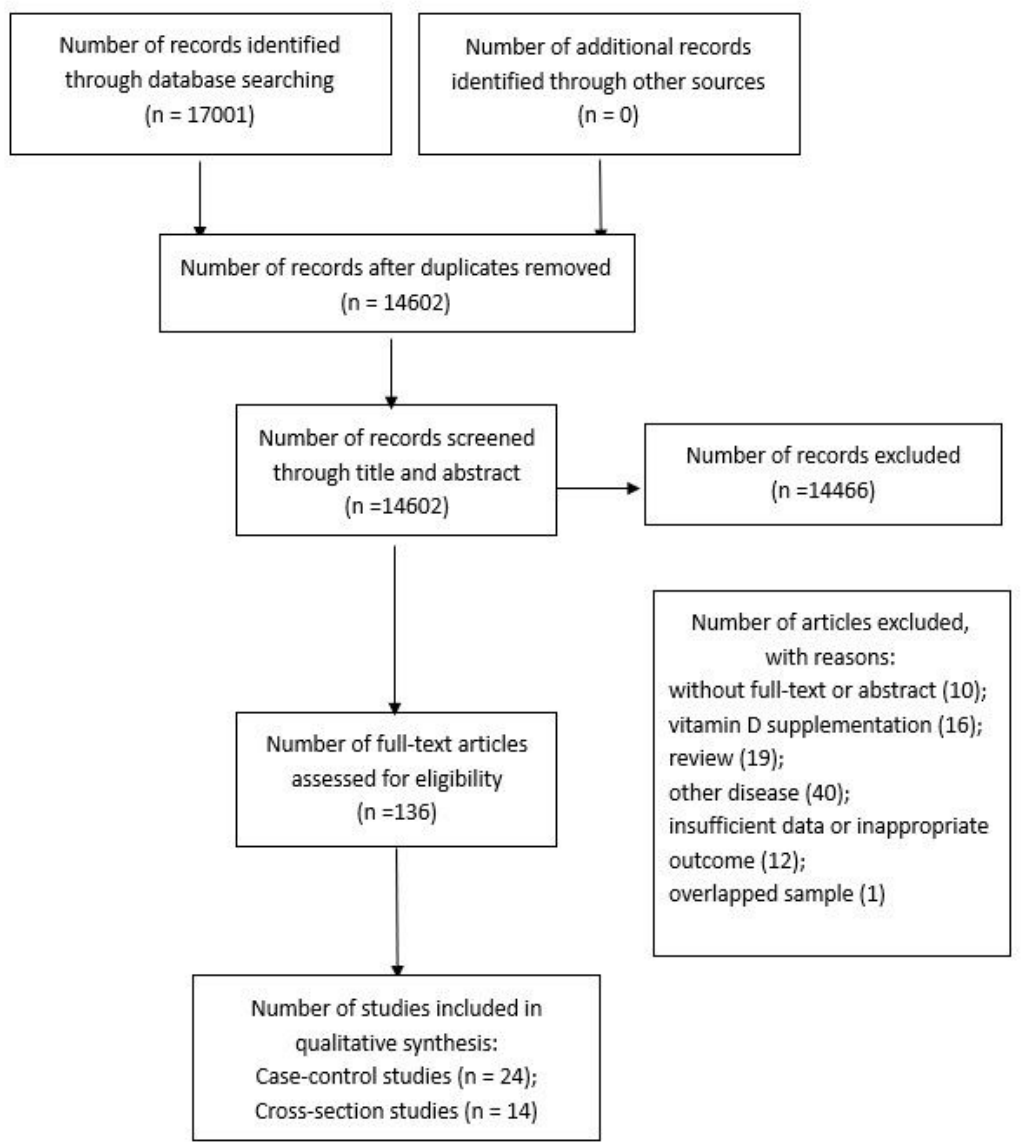

Figure 1

Flow chart of literature searching 
Study

\section{ID}

Case-control Studies Doknic-2011

Rey-Sánchez-2009 (1)

Schneider-2000

Higuchi-1987

Salavert-2017

Grados-2015

Akinlade-2017

Bergemann-2008

Yuksel-2014 (8)

Zhu-2015

Clelland-2014

Itzhaky-2012

Yazici, AB-2019 (4)

Norelli-2010

Rey-Sánchez-2009 (2)

Endres-2016

Jamilian-2013

Yazici, AB-2019 (3)

Yazici, E-2019 (6)

Graham-2015

Ikonen-2019

Kulaksizoglu-2017

Bulut-2016

Yuksel-2014 (7)

Yazici, E-2019 (5)

Subtotal $(l-$ squared $=96.9 \%, p=0.000)$

Cross-section Studies

Humber-2010

Menkes-2012

Boerman-2016

Lally-2016

Partti-2010

Bazzano-2016

Patel-2018

Abdullah-2012

Subtotal (l-squared $=57.3 \%, p=0.022$ )

Overall (l-squared $=96.1 \%, p=0.000$ )

NOTE: Weights are from random effects analysis

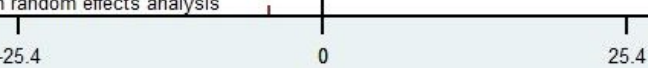

$\%$

Weight

$-19.54(-20.72,-18.36) \quad 3.44$

$-12.70(-25.44,0.04) \quad 1.59$

$-10.80(-22.00,0.40) \quad 1.81$

$-9.70(-11.45,-7.95) \quad 3.40$

$-9.49(-13.54,-5.44) \quad 3.10$

$-8.58(-21.00,3.84) \quad 1.64$

$-8.31(-10.71,-5.91) \quad 3.33$

$-8.30(-11.54,-5.06) \quad 3.23$

$-7.02(-8.80,-5.24) \quad 3.39$

$-6.93(-8.57,-5.29) \quad 3.41$

$-5.43(-12.69,1.83) \quad 2.51$

$-5.20(-8.19,-2.21) \quad 3.26$

$-4.56(-8.27,-0.85) \quad 3.16$

$-3.20(-9.58,3.18) \quad 2.68$

$-3.01(-8.53,2.51) \quad 2.84$

$-3.00(-5.51,-0.49) \quad 3.32$

$-2.52(-3.73,-1.31) \quad 3.44$

$-2.34(-5.14,0.46) \quad 3.29$

$-2.32(-4.77,0.13) \quad 3.33$

$-1.70(-10.05,6.65) \quad 2.30$

$-1.10(-2.48,0.28) \quad 3.43$

$-0.80(-1.92,0.32) \quad 3.44$

$-0.23(-4.00,3.54) \quad 3.15$

$0.05(-2.09,2.19) \quad 3.36$

$2.51(-4.16,9.18) \quad 2.62$

$-5.19(-7.90,-2.48) \quad 74.46$

$-5.10(-7.62,-2.58) \quad 3.32$

$-4.80(-7.94,-1.66) \quad 3.24$

$-3.40(-5.93,-0.87) \quad 3.32$

$-2.80(-4.65,-0.95) \quad 3.39$

$-1.90(-6.32,2.52) \quad 3.04$

$-1.70(-5.76,2.36) \quad 3.10$

$-1.20(-7.03,4.63) \quad 2.78$

$1.00(-1.25,3.25) \quad 3.35$

$-2.60(-4.20,-0.99) \quad 25.54$

$-4.50(-6.69,-2.32) \quad 100.00$

Figure 2 


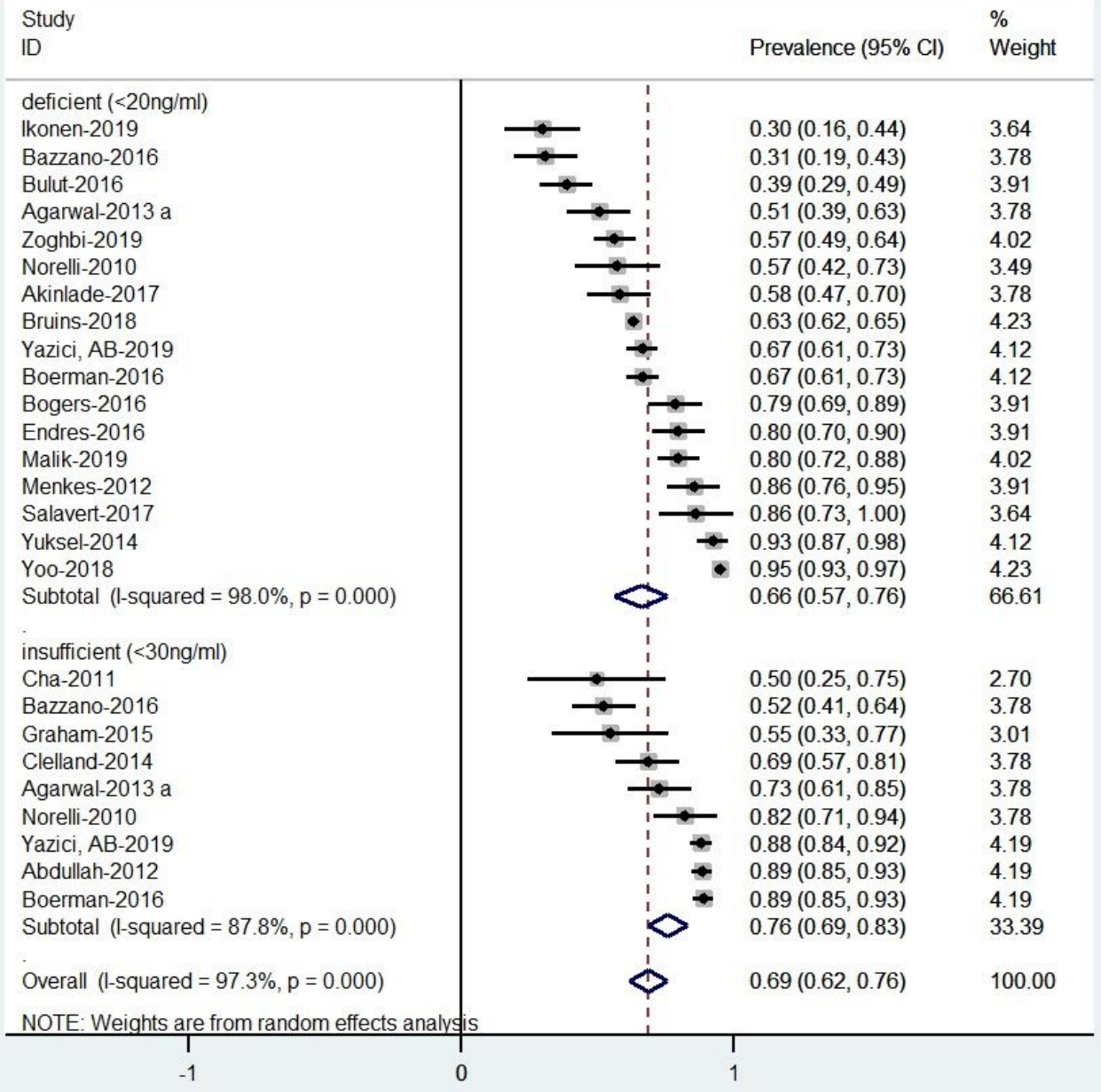

Figure 3 


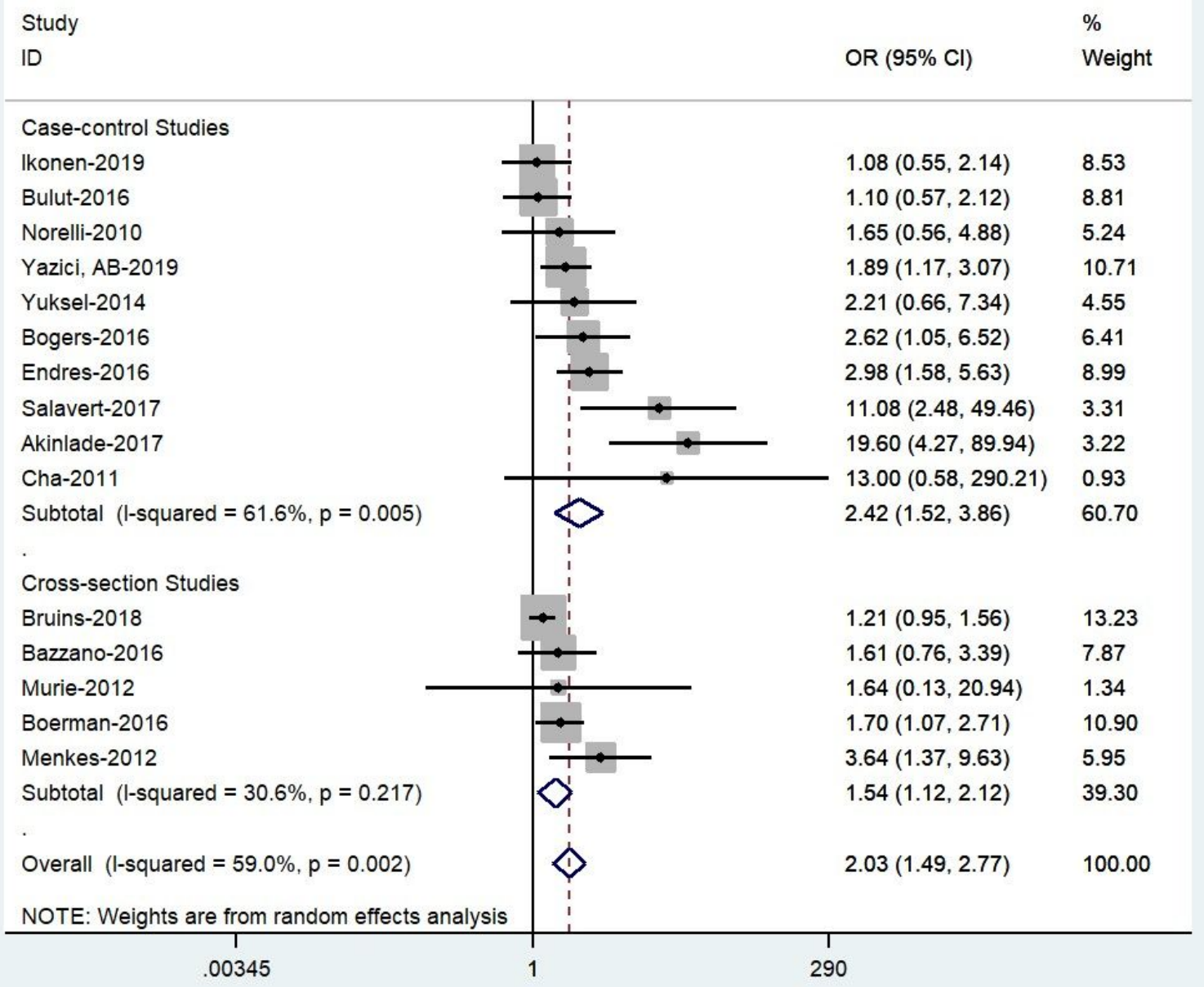

Figure 4 
Study

ID

Cross-section Studies

Abdullah-2012

Boerman-2016

Bazzano-2016

Subtotal (l-squared $=64.6 \%, p=0.059$ )

Case-control Studies

Norelli-2010

Yazici, AB-2019

Clelland-2014

Endres-2016

Itzhaky-2012

Cha-2011

Akinlade-2017

Subtotal (l-squared $=63.2 \%, p=0.012$ )

Overall (I-squared $=62.9 \%, p=0.004)$

NOTE: Weights are from random effects analysis
$\%$

OR $(95 \% \mathrm{Cl})$

Weight

$\begin{array}{ll}2.09(1.11,3.92) & 14.81 \\ 2.46(0.84,7.20) & 10.83 \\ 1.48(0.66,3.33) & 38.40\end{array}$

$1.18(0.30,4.62) \quad 8.64$

$1.21(0.60,2.45) \quad 14.14$

$2.51(1.28,4.92)$

$5.33(1.66,17.06) \quad 10.11$

$6.70(0.78,57.88) \quad 4.83$

$17.22(1.78,166.98) \quad 4.47$

$34.16(4.14,282.13) \quad 4.98$

$3.49(1.61,7.57) \quad 61.60$

$2.43(1.40,4.23) \quad 100.00$

Figure 5 


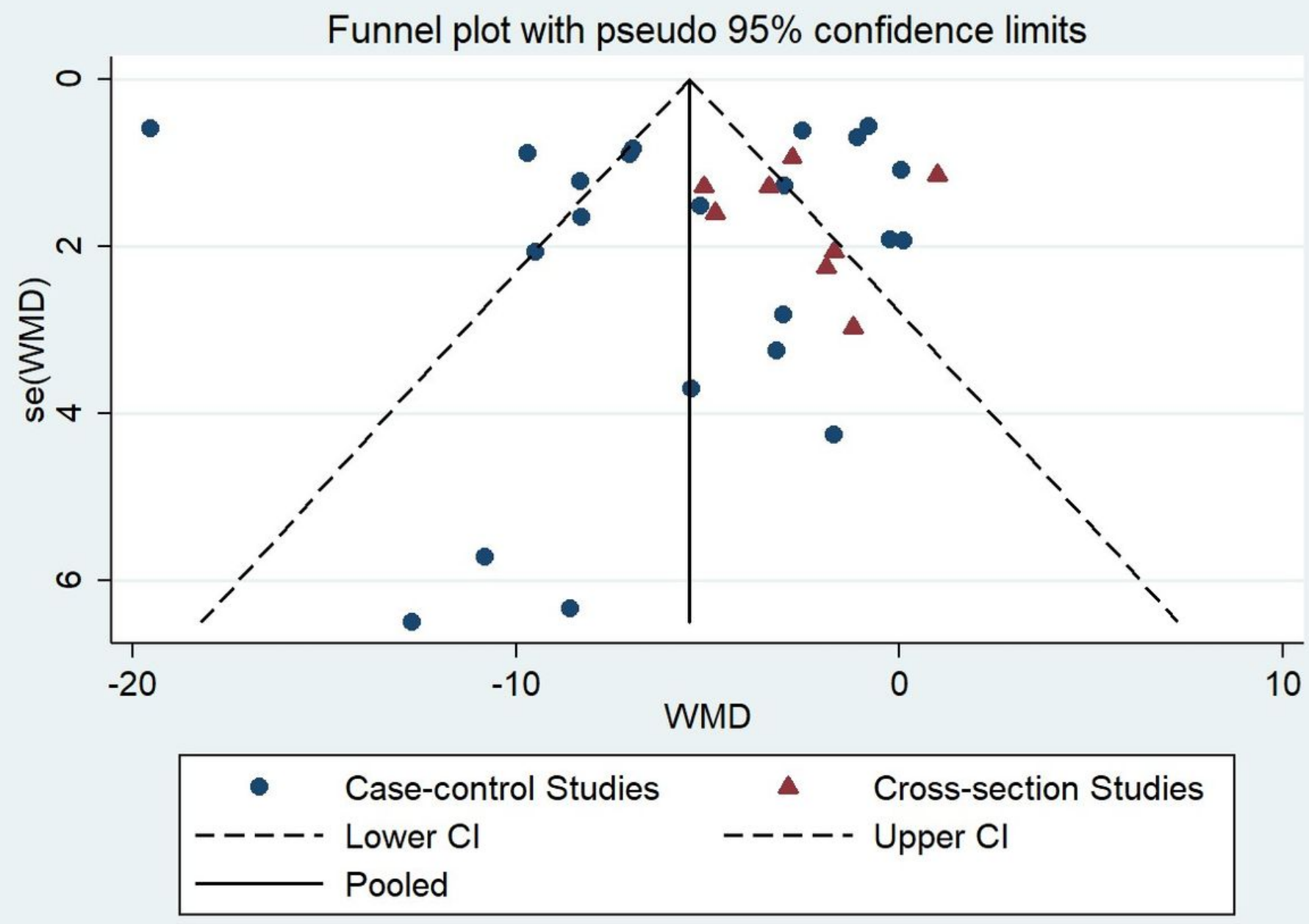

Figure 6 


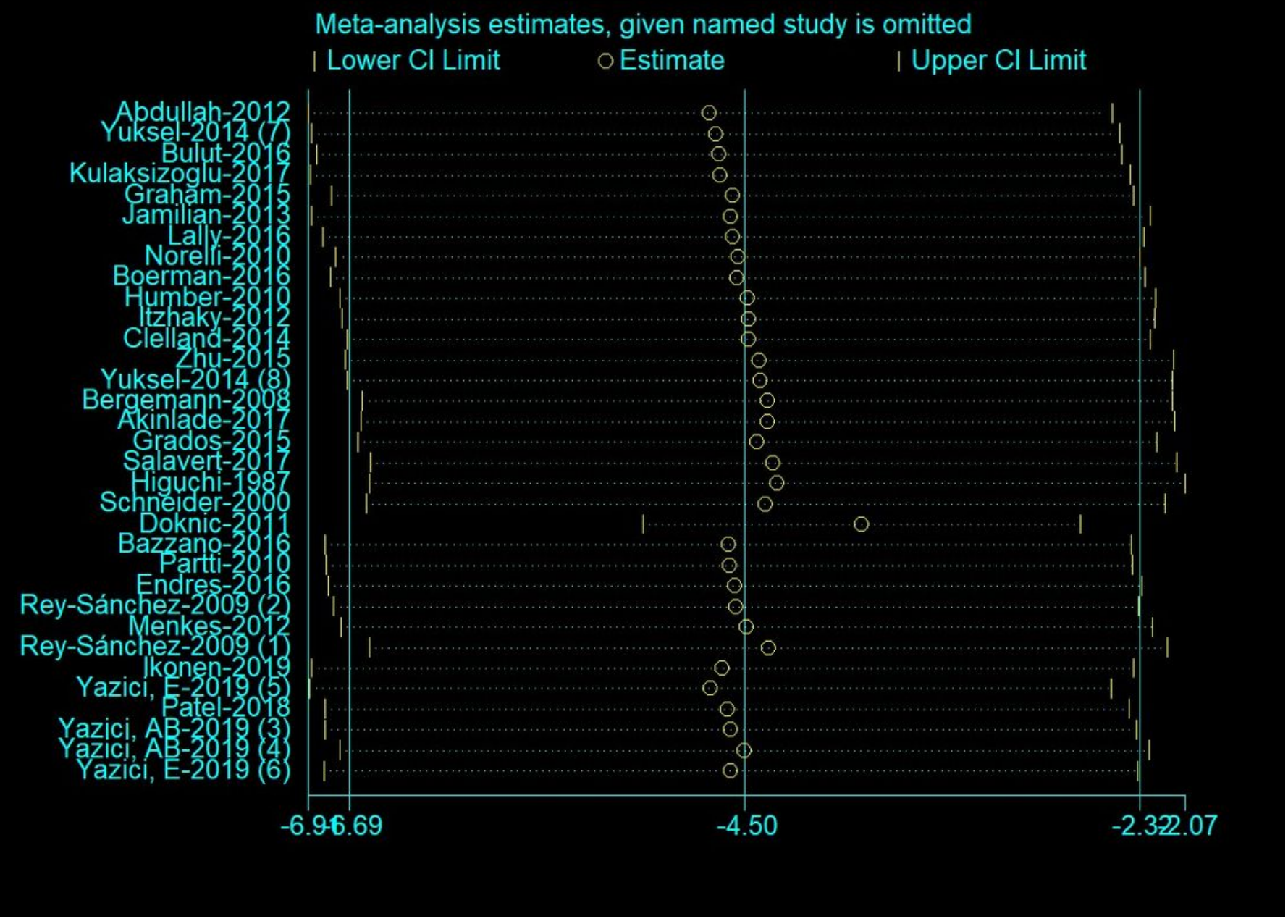

Figure 7

\section{Supplementary Files}

This is a list of supplementary files associated with this preprint. Click to download.

- PRISMA2009checklist.doc 